\title{
Viral gametocytic hypertrophy caused by a papova-like virus infection in the Pacific oyster Crassostrea gigas in Korea
}

\author{
Dong Lim Choi ${ }^{1, *}$, Nam-Sil Lee ${ }^{1}$, Hee Jung Choi ${ }^{1}$, Myoung-Ae Park ${ }^{1}$, \\ Sharon E. McGladdery ${ }^{2}$, Mi Seon Park ${ }^{1}$
}

${ }^{1}$ Pathology Division National Fisheries Research and Development Institute, Gijang, Busan 619-902, Republic of Korea

${ }^{2}$ Shellfish Pathology National Aquatic Animal Health, DFO Gulf Fisheries Centre DFO National Headquarters, 343 University Avenue, Moncton, Ottawa K1A 0E6, Canada

\begin{abstract}
During a routine survey of the Pacific oyster Crassostrea gigas in Tongyoung (previously Chungmu) on the southern coast of Korea, basophilic inclusions were observed in the gonadal tissues. They were detected from March to May at a prevalence rate of 3.3 to $7.1 \%$. The inclusion bodies were Feulgen-positive and stained orange-red with phloxine tartrazine. Electron microscopic observation revealed non-enveloped, icosahedral particles 40 to $45 \mathrm{~nm}$ in diameter. These morphological characteristics resemble those of papova virus-like inclusions previously described from Pacific and eastern (American) oysters C. virginica in North America. Although many mitochondrial bodies and intact sperm cells were observed around the inclusion body, no host reaction, such as hemocytic infiltration, was detected.
\end{abstract}

KEY WORDS: Pacific oyster · Crassostrea gigas · Viral gametocytic hypertrophy · Papova-like virus · Seminal gland Resale or republication not permitted without written consent of the publisher

\section{INTRODUCTION}

Tongyoung (previously Chungmu) is an important area for oyster culture in Korea; however, production has declined significantly over the last decade. One of the reasons for this decline is mortality due to infectious disease. Marteilioidosis, caused by the protistan parasite Marteilioides chungmuensis, is one of the main oyster diseases (Comps et al. 1987), but other diseases may also be contributing to these mortalities and have yet to be properly investigated.

Papova-like viruses have been reported from the labial palp epithelial of gold-lipped pearl oysters in northern Australia (Norton et al. 1993) and from the gonadal epithelia of Crassostrea virginica in Canada (McGladdery \& Stephenson 1994) and the USA (Meyers 1981, Farley 1985, Winstead et al. 1998, Winstead \& Courtney 2003), as well as from other bivalve species (Elston 1997). During a recent health survey of cul- tured oysters from the Tongyoung area, papova-like virus was observed in gonadal tissues. This is the first confirmed report of this virus in C. gigas from Korea.

\section{MATERIALS AND METHODS}

Pacific oysters Crassostrea gigas 1 to 2 yr old, cultured at Tongyoung on the southern coast of Korea, were collected from October 2001 to November 2002. From 6 sites (Fig. 1), 30 oysters were randomly collected each month (total of 2340 oysters). Individual lengths were recorded along with gross and microscopic observations. For histological analysis, tissue samples were fixed in Carson's fixative solution (OIE 2000) and Davidson's fixative solution (Howard \& Smith 1983).

Histological examination. Oyster tissues fixed in Davidson's solution were processed for paraffin- 


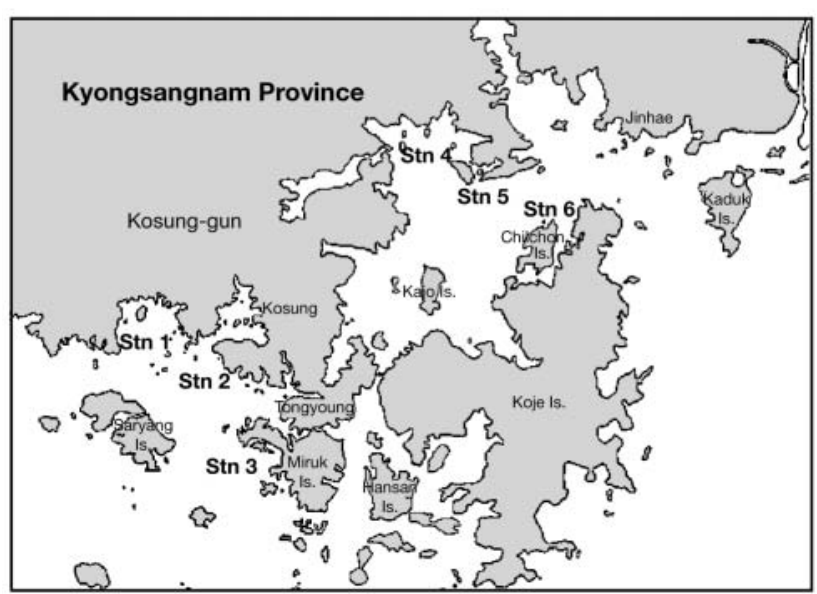

Fig. 1. Sampling stations in Tongyoung on the southern coast of Korea

embedding and cut into $4 \mu \mathrm{m}$ thick sections. Some sections were stained with Harris's hematoxylin and eosin (H\&E), some with Feulgen stain and some with phloxine tartrazine, for bright field light microscopy (Olympus Vanox AHBS3) examination.

Ultrastructural examination. Samples showing inclusion bodies within the gonadal epithelia were selected for processing for transmission electron microscopy. Tissue specimens from the same oysters, preserved in Carson's fixative solution were rinsed in $0.2 \mathrm{M}$ cacodylate buffer at $\mathrm{pH} 7.2$ for $48 \mathrm{~h}$ at $4^{\circ} \mathrm{C}$ before post-fixing in $2.5 \%$ glutaraldehyde solution, and $1 \%$ osmium tetroxide. After dehydration through graded alcohols, the tissues were embedded in Epon resin compound (Ouken, Japan). Hardening was carried out at $35^{\circ} \mathrm{C}$ for $12 \mathrm{~h}, 45^{\circ} \mathrm{C}$ for $12 \mathrm{~h}$, and $60^{\circ} \mathrm{C}$ for
$48 \mathrm{~h}$. Semi-thin sections $(200 \mathrm{~nm})$ were stained with toluidine blue, and ultra-thin sections $(60 \mathrm{~nm})$ were stained with uranyl acetate and lead citrate. Ultra-thin sections were examined with a JEOL 1200 EX-2 transmission electron microscope (TEM) at $80 \mathrm{kV}$.

\section{RESULTS}

Basophilic inclusions in gonoducts were observed in specimens from all sites except Stn 4 . Infections were observed from March to May at prevalences of 3.3 to $7.1 \%$. Prevalence at Stn 3 was higher than at the other sites (Table 1). The heaviest infection included 62 inclusion bodies in a single tissue section; however, no host reaction was observed. The longest axis of the inclusion bodies varied from 15 to $60 \mu \mathrm{m}$, and the shape was oval to spherical. Some inclusion bodies had dense staining margins (Figs. 2 \& 3). Feulgen staining confirmed the presence of dense nucleic acid (Fig. 4), and orange-red staining with phloxine tartrazine (Fig. 5) demonstrated a deoxyribonucleic acid (DNA) composition. Advanced infections led to disruption of the nuclear membrane and putative release of the viral particles (Fig. 4, arrowhead).

Non-enveloped, icosahedral viral particles, 40 to $45 \mathrm{~nm}$ in diameter, filled the inclusion bodies (Figs. 6 \& 7). These morphological characteristics resemble those of Papovaviridae. The chromophilic margins observed by light microscopy were identified as peripherally displaced chromatin. Many mitochondria were arranged around the intranuclear inclusion bodies. Spermatozoa were scattered around the inclusion bodies (Fig. 8), and few free virus particles were observed around inclusion bodies (Fig. 9).

Table 1. Crassostrea gigas. Prevalence of viral gametocytic heterotrophy (VGH) in oysters sampled at 6 stations in Tongyoung area, southern coast of Korea. Data are no. infected/no. sampled (\% prevalence). -: not detected; ns: not sampled; shaded values: infection period

\begin{tabular}{|c|c|c|c|c|c|c|}
\hline Date & Stn 1 & Stn 2 & Stn 3 & Stn 4 & Stn 5 & Stn 6 \\
\hline \multicolumn{7}{|l|}{2001} \\
\hline October & $-/ 30$ & $-/ 30$ & $-/ 30$ & $-/ 30$ & $-/ 30$ & $-/ 30$ \\
\hline November & $-/ 30$ & $-/ 30$ & $-/ 30$ & $-/ 30$ & $-/ 30$ & $-/ 30$ \\
\hline December & $-/ 30$ & $-/ 30$ & $-/ 30$ & $-/ 30$ & $-/ 30$ & $-/ 30$ \\
\hline \multicolumn{7}{|l|}{2002} \\
\hline January & $-/ 30$ & $-/ 25$ & $-/ 30$ & $-/ 25$ & $-/ 25$ & $-/ 25$ \\
\hline February & $-/ 30$ & $-/ 28$ & $-/ 30$ & $-/ 30$ & $-/ 25$ & $-/ 25$ \\
\hline March & $-/ 28$ & $-/ 30$ & 1/30(3.33) & $-/ 30$ & $1 / 30(3.33)$ & $1 / 20(5)$ \\
\hline April & 1/30 (3.33) & $1 / 30(3.33)$ & $2 / 28(7.14)$ & $-/ 27$ & $-/ 22$ & $1 / 29(3.45)$ \\
\hline May & 1/30 (3.33) & $2 / 30(6.67)$ & $1 / 30(3.33)$ & $-/ 30$ & $1 / 30(3.33)$ & $-/ 30$ \\
\hline June & $-/ 30$ & $-/ 30$ & ns & $-/ 30$ & $-/ 24$ & ns \\
\hline July & $-/ 29$ & $-/ 30$ & ns & $-/ 26$ & $-/ 18$ & ns \\
\hline August & $-/ 28$ & $-/ 30$ & ns & $-/ 22$ & $-/ 25$ & ns \\
\hline October & $-/ 30$ & $-/ 30$ & $-/ 30$ & $-/ 30$ & $-/ 30$ & $-/ 30$ \\
\hline November & $-/ 30$ & $-/ 27$ & $-/ 30$ & $-/ 28$ & $-/ 21$ & $-/ 24$ \\
\hline
\end{tabular}


Figs. 2-5. Crassostrea gigas. Fig. 2. Basophilic homogeneous inclusion bodies (arrows) are among germ cells in reproductive gland of male; surrounding tissue lacks necrotic cells (H\&E) $($ scale bar $=35 \mu \mathrm{m})$. Fig. 3 . Inclusion body is organized into a ring-like structure of condensed chromatin; unstained regions outside and inside the inclusion body (H\&E) (scale bar $=20 \mu \mathrm{m})$. Fig. 4. Feulgen-positive inclusion body (arrow) and other structure (arrowhead) with indistinct outline and spotted chromatin debris (Feulgen reaction) (scale bar $=25 \mu \mathrm{m}$ ). Fig. 5 . Inclusion body (arrow) with several nuclei at its margin and stained orange-red (phloxine tartrazine) (scale bar $=25 \mu \mathrm{m})$
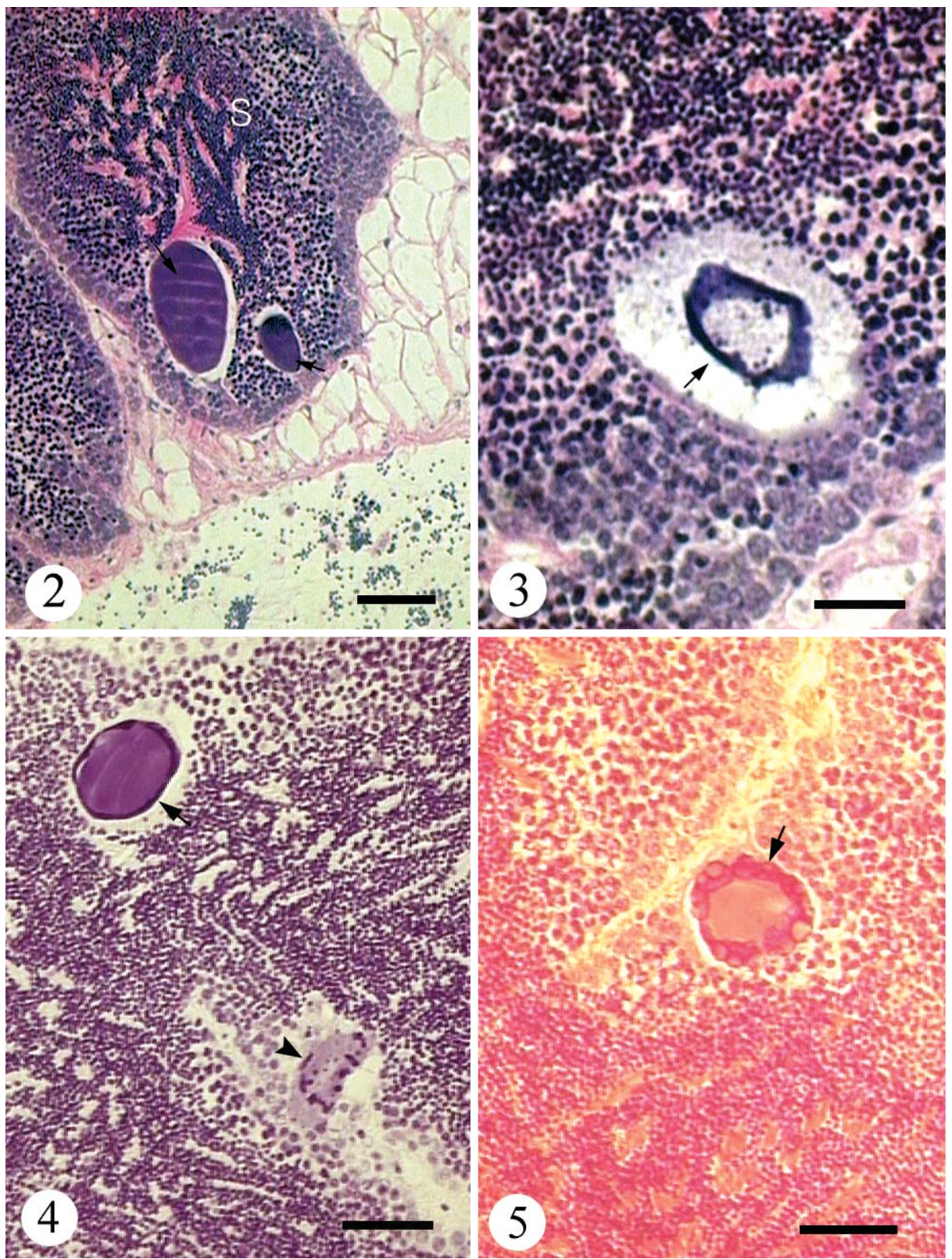

\section{DISCUSSION}

Based on ultrastructural morphological characteristics and staining properties, these viruses appear consistent with those previously described as papova-like (Dimmock \& Primrose 1994, Ackermann \& Berthiaume 1995, p. 63-64) from gonoduct lesions in oysters from North America (Crassostrea gigas, C. virginica, Ostrea lurida, O. edulis) and Australia (C. commercialis) (Farley 1976, 1978, 1985, McGladdery \& Stephenson 1994, Winstead et al. 1998, Winstead \& Courtney 2003). Infections of labial palp epithelia in Pinctada maxima (gold-lipped pearl oyster) were determined to be caused by a similar virus (Norton et al. 1993).

In vertebrates, Papovaviridae include the papillomoviruses responsible for warts, papillomas and related skin disorders. The family also includes the polyomaviruses responsible for polio disease.

The viruses detected in the present study appear to match the size range described for the polyomaviruses; however, those of Crassostrea virginica appear to be more closely associated with the papillomaviruses (McGladdery \& Stephenson 1994, McGladdery 1999). No papilloma-like lesions were detected; however, 

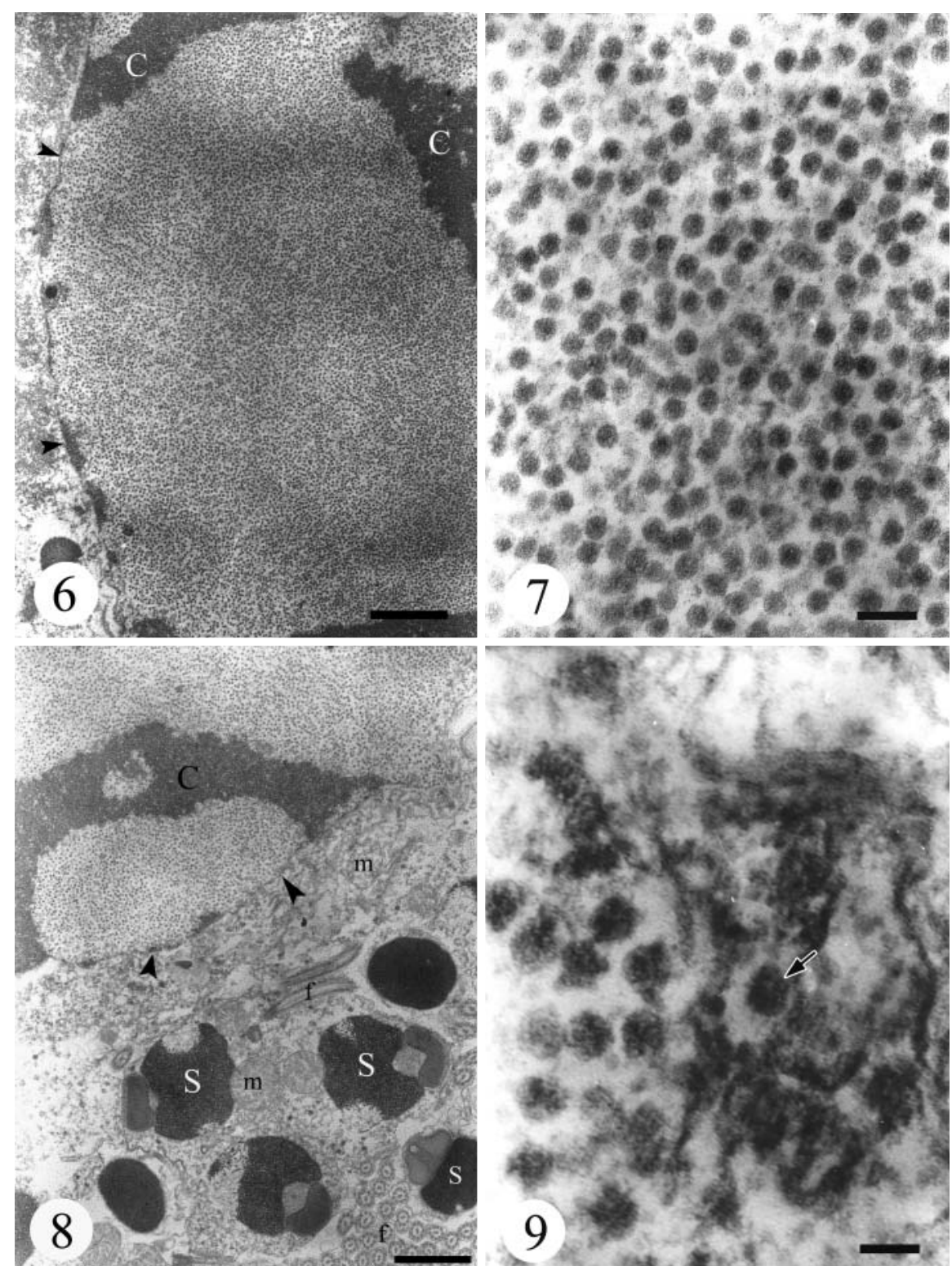

Figs. 6-9. Crassostrea gigas. Fig. 6. Transmission electron micrograph of inclusion body, filled with viral particles, arrowheads: edge of inclusion body; C: condensed chromatin; scale bar $=1 \mu \mathrm{m}$. Fig. 7. Details of viral particles, non-enveloped, icosahedral and 40 to $45 \mathrm{~nm}$ in diameter; scale bar $=100 \mathrm{~nm}$. Fig. 8. Transmission electron micrograph of inclusion body and surrounding tissue; arrowheads: edge of inclusion body; $\mathrm{C}$ : condensed chromatin; m: mitochondria; $\mathrm{S}$ : head of spermatozoa; $\mathrm{f}$ : flagella of spermatozoa; scale bar = $1 \mu \mathrm{m}$. Fig. 9. Released virus particle (arrow) outside inclusion body; scale bar $=50 \mathrm{~nm}$

viral proliferation causes significant hypertrophy and compression of gonoduct space available for gametogenesis. Single cells appear to be infected, with no evidence in the current study (or previously published observations of similar infections) of neoplastic proliferation of infected cells/tissues. No adverse effect was noted on oyster health; however, if the viral infections were to become more intense, the effect on fecundity would need to be assessed.

Infections were noted in March, April and May, with no clear link to environmental factors over this period, except possibly to increased water temperature. Further study is required to clarify the seasonal dynamics and relation to the normal oyster gametogenesis cycle.
In Korea, reproduction of oysters depends mostly on the collection of natural spat. Viral gametocytic hypertrophy (VGH) would affect the reproduction of oysters, but it would be difficult to quantify this effect. Most cultured oysters collected in spring are harvested before the second summer to avoid summer mortality. VGH may become a problem in Korea and also worldwide. Thus, its impact should be the subject of further studies.

Acknowledgements. We thank K. R. Cho (Inje Medical University, Busan, Korea) for technical assistance. Drs. H. S. Byon and K. T. Sohn (NFRDI, Busan, Korea) are acknowledged for providing biological samples. This work was supported by the Ministry of Maritime Affairs and Fisheries Special Grants for Fisheries Research and Development Project in Korea. 


\section{LITERATURE CITED}

Ackermann HW, Berthiaume L (1995) Atlas of virus diagrams. CRC Press, Boca Raton, FL

Comps M, Park MS, Desportes I (1987) Fine structure of Marteilioides chungmuensis n. g. n. sp., parasite of the oocytes of the oyster Crassostrea gigas. Aquaculture 67: $264-265$

Dimmock NJ, Primrose SB (1994) Introduction to modern virology, 4th edn. Blackwell Science, Oxford

Elston R (1997) Special topic review: bivalve mollusc viruses. World J Microbiol Biotechnol 13:393-403

Farley CA (1976) Ultrastructural observations on epizootic neoplasia and lytic virus infection in bivalve mollusks. Prog Exp Tumor Res 20:283-294

Farley CA (1978) Viruses and virus-like lesions in marine molluscs. Mar Fish Rev 40:18-20

Farley CA (1985) Viral gametocytic hypertrophy in oysters. In: Sindermann CJ (ed) Identification leaflets for diseases and parasites of fish and shellfish, No. 25. ICES, Copenhagen, p 1-5

Howard DW, Smith CS (1983) Histological techniques for bivalve mollusks. NOAA Tech Memo NMFSF/NEC-25: $1-97$

Editorial responsibility: Albert Sparks,

Seattle, Washington, USA
McGladdery SE (1999) Shellfish diseases (viral, bacterial and fungal) In: Woo PTK, Bruno DW (eds) Fish diseases and disorders, Vol 3, Viral, bacterial and fungal infections. CAB International, Oxon, p 723-842

McGladdery SE, Stephenson MF (1994) A viral infection of the gonads of eastern oyster (Crassostrea virginica) from Atlantic Canada. Bull Aquac Assoc Can 94:84-86

Meyers TR (1981) Endemic diseases of cultured shellfish of Long Island, New York: adult and juvenile American oysters (Crassostrea virginica) and hard clams (Mercenaria mercenaria). Aquaculture 22:305-330

Norton JH, Shepherd MA, Prior HC (1993) Papovaviruslike infection of the golden-lipped pearl oyster, Pinctada maxima, from the Torres Strait, Australia. J Invertebr Pathol 62:198-200

OIE (Office International des Epizooties) (2000) Diagnostic manual for aquatic animal diseases, 3rd edn. OIE, Paris, p 129-134

Winstead JT, Courtney LA (2003) Ovacystis-like condition in the eastern oyster Crassostrea virginica from the northeastern Gulf of Mexico. Dis Aquat Org 53:89-90

Winstead JT, Overstreet RM, Courtney LA (1998) Novel parasites in the eastern oyster Crassostrea virginica from two Gulf of Mexico bays. J Shellfish Res 17:341-342

Submitted: March 19, 2003; Accepted: December 31, 2003 Proofs received from author(s): May 5, 2004 